\title{
The resilience of social logistics systems-The concept and pilot studies
}

\author{
Mateusz Zaczyk* \\ Silesian University of Technology, Gliwice, Poland
}

\section{Keywords \\ Logistic system \\ Resilience \\ Social logistics \\ Social needs \\ Vulnerability}

Received: 11 February 2019

Accepted: 12 March 2019

Published: 24 April 2019

\begin{abstract}
The article presents basic assumptions defining the resilience of logistic systems aimed at satisfying societies' needs. It focused on the special importance of system theory for the contemporary understanding of management sciences, emphasizing logistics. Based on the current state of literature, the article characterizes the concept of social logistics as one of three basic types of logistics. The importance of identifying key social needs in order to understand the essence of social logistics was also emphasized. The article contains a proposition of elements that can be a part of the social logistics system, deliberately shaped by the selected subjects, and the characteristics of connections between them. In addition to that, a composition of key factors, increasing the vulnerability of social logistics systems, and a set of measures to strengthen the resilience of the systems were proposed. The second part of the article presents the concept of conducting empirical research in the resilience of social logistics systems, conducted among representatives of secondary schools and higher educational institutions from a highly industrialized region of southern Poland. The article contains the results of pilot studies carried out on the abovementioned research sample, which is an important element shaping further research. As part of the pilot studies, both qualitative and quantitative researches were conducted. The research led to the compilation of a set of the most important vulnerability points of social logistics systems and factors that could strengthen their resilience from the point of view of southern Poland society representatives.
\end{abstract}

(C) 2019 The Author(s). Published by TAF Publishing

\section{INTRODUCTION}

During the past decade, the concept of social logistics has begun to crystallize. Some scientists started to understand it as one of three pure types of logistics, on equal terms with economic and military logistics (Michlowicz, 2002). This phenomenon emerged from observation that there is a difference in the key goal of those who implement logistics activities, as well as in different ways of reaching this goal. In this article, the author presented basic assumptions on defining the term "social logistics". In addition to that, the article presents a proposal for the composition of the social logistics system based on observation of the activities of social entities and in-depth analysis of literature. An important element of the article is an attempt to relate the concept of a system's resilience to social logistics issues. The second part of the article presents the concept of conducting empirical research in the field of the re- silience of social logistics systems with the results of pilot studies conducted among representatives of secondary and higher schools from a highly industrialized region of southern Poland. The article contains the results of pilot studies carried out on the above-mentioned research sample, which are an important element shaping the course of further research. As part of the pilot studies, both qualitative and quantitative researches were conducted. The research led to the compilation of a set of the most important factors that could strengthen their resilience from the point of view of southern Poland society representatives.

\section{THE CONCEPT OF SOCIAL LOGISTICS}

Reflections on the concept of social logistics system, proposed in this article, should begin with an interpretation of the concept of a system that is well-established in management sciences and results from the general theory of sys-

${ }^{*}$ corresponding author: Mateusz Zaczyk

†email: mateusz.zaczyk@polsl.pl 
tems. This theory is currently an interdisciplinary category, and its sources should be traced to biological sciences. Already in the initial phase of the creation of general system theory, L. von Bertalanfye still formulated the current definition of the system assuming that it is "a set of elements in mutual relations" (Niedzielska, 1998; Piyachat, 2017; Von Bertalanffy, 1984). Over the years, system theory has undergone systematic development on the basis of cybernetics and engineers from various areas of engineering activity. Nowadays, system theory finds application in countless areas of functioning of both the living organisms (which refers to its original sources), as well as technical devices or economic structures, but also societies, which requires seeking its application in the field of social logistics, positioned in the field of management sciences (Coyle, Bardi, \& Langley, 2007). Management itself, as the main subject of interest in management sciences, is treated as systemic activity, which is associated with the emergence of cybernetic management models assuming the existence of controlling and controlled elements (Bhalerao, 2016; Rudolf, 2002) while logistic system is understood as "a set of logistic elements whose connections are concretized through transformation processes" (Blaik \& Logistyka, 2001) or "a network of organizations, people, activities, information, and resources involved in the physical flow of products from supplier to customer" (Fahimnia, Molaei, \& Ebrahimi, 2011). This article focuses on a specific type of logistic systems - social logistics system.

\section{Social Logistics in the Literature}

Modern understanding of logistics assumes the existence of its military origin, which shows a tendency to focus on transport and storage processes, as well as to pay attention to minimizing total costs (Szołtysek, Sadowski, \& KalisiakMędelska, 2016). After transferring the rules used in the military sphere to the broadly understood business, the concept of business - or economic logistics - was created. This way, scientists began to talk about two "pure" types of logistics - military and economic logistics. On the other hand, scientists' opinions on the legitimacy of separating individual types of logistics were strongly divided. However, there was no doubt about the adoption of improving material and information flows as the essence of logistics activities (Klumpp \& Zijm, 2019; Krzyżanowski, 1994). Rules governing the decision-making process on the actions taken can be understood in various ways for different types of lo- gistics (Han \& Trimi, 2018). In connection with the adoption of the above thesis, the author of this article supports the opinion of scientists who consider it to be justified to separate the two types of logistics mentioned above. They also acknowledge that consideration should be given to the recognition of social logistics as the third "pure" type of logistics. Their opinion motivates the perception of difference in the main goals of entities operating in the area of a given type of logistics and, in particular, the difference in the manner of achieving these goals.

Asian authors were one of the first scientists dealing with the topic of social logistics, and the trend of taking social actions began to be also noticed in the activities of entrepreneurs, who would traditionally be positioned as part of economic logistics. In the studies of Asian creators, one can come across the scope of interest in social logistics. However, guided by the business perspective. According to Tanimoto, social logistics is "creating, maintaining, regulating and taxing the infrastructure, within which the enterprises operate, with particular emphasis on the conditions of transport, communication, control, settlements with the public budget and crisis management (Szołtysek et al., 2016)". Tanimoto, therefore, emphasizes the close link between social and economic logistics, which brings his position closer to the modern concept of public management, which assumes drawing on the achievements of economic logistics and the experience of enterprises to manage public units. However, similarly to the need to separate social logistics as a separate type of logistics, the opinions of scientists are divided, as it is sometimes even acknowledged that the excessive combination of social and economic logistics can become a braking force for the former. A different approach to the positioning of social logistics determines its place within global logistics. In his mind, social logistics is one of three layers (Szołtysek et al., 2016).

Regardless of the way of positioning the social logistics in relation to its other types, as the main premise for the necessity of its proper separation, scientists adopt a focus on satisfying the needs of beneficiaries of the shaped social logistics system. This satisfaction is the primary goal of social logistics, and this statement is at the core of most attempts to define this concept found in the literature. These attempts did not always end with the full definition of the term; although, they suggested key elements. Selected elements of the definition of social logistics are presented in Table 1. 
TABLE 1. Elements of the definition of social logistics

\begin{tabular}{ll}
\hline \hline Author & Elements of Definition \\
\hline Trujillo (2009) & $\begin{array}{l}\text { Social logistics is one of three layers of global logistics that links the strategic value of flows in the } \\
\text { business sphere with the social system. } \\
\text { Gallopin, Hammond, Raskin, and Swart (1997) }\end{array}$ \\
$\begin{array}{l}\text { Social logistics is used to confront society's needs in terms of material effectively flows with possible } \\
\text { ways of satisfying them. } \\
\text { Saonkar and Viswanadham (2007) }\end{array}$ & $\begin{array}{l}\text { Social logistics is oriented at providing all the different flows, necessary to meet the needs of residents. } \\
\text { Szołtysek et al. (2016) } \\
\text { order to obtain specific space-time values, resulting from the needs of society and ensuring its proper } \\
\text { functioning. }\end{array}$ \\
\hline \hline
\end{tabular}

Source: (Gallopin et al., 1997; Gaonkar \& Viswanadham, 2007; Trujillo, 2009; Szołtysek et al., 2016)

Table 1 shows that, regardless of the way of thinking about social logistics, one should notice the special importance of society's needs for the existence of social logistics. The definition coined by Szołtysek, Sadowski, and KalisiakMedelska seems to define the essence of social logistics properly and will be the starting point for further considerations contained in this article. The authors of this definition also indicated 5 features, related to the management process, that distinguish pure individual types of logistics dominant premise for decisions, the priority of actions, guiding principles, subject and main goal (Szołtysek et al., 2016). In terms of these features, one can easily see significant differences between the types of logistics. In this case, the quality of society's life was defined as the priority of management actions. It will provide a starting point for considerations focused on determining social needs, that are an incentive to shape the flows necessary to meet them. According to the definition taken from the PWN Encyclopedia, the quality of life is understood as "a degree of satisfying the material and intangible needs - meeting standards or realizing biological, psychological, spiritual, social and political, cultural, economic and ecological units, families and collectivity; the concept used in social policy, psychology, medicine, economics and sociology" (Parast, Sabahi, \& Kamalahmadi, 2019). In the context of social logistics, the above definition describes the presence of social needs as crucial in terms of the quality of life, as well as the presence of a defined concept in economics (McGihon, Hawke, Chaim, \& Henderson, 2018). This suggests the validity of the considerations contained in this article. Focusing on social needs, one should mention their definition and a number of social needs appearing in the literature on the subject. The notion of needs, as a part of a wide spectrum of scientific disciplines or fields of life, results in an inconclusive ambiguity in understanding it. This article focuses on understanding the concept of need in the context of economic sciences. The lack of a theory of needs in social sciences made it necessary to establish their definition in relation to psychological concepts. In literature, however, one can also see a departure from the psychological understanding of needs, towards functional and systemic concepts. The authors of this article adopt two definitions of systemic needs (Zbróg, 2011). The first states that "Need is something that, in relation to the biology of an individual, its social role, group culture, experience, and current situational conditions, in which it operates, creates not only a sense of satisfaction (or lack thereof) in specific matters, but also (if the need is met) a sense of meaning in this satisfaction". Thus, it suggests the importance of social roles being on par with the biological conditions of human life. The second, however, assumes that "The need of a system is a feature, because of which a condition of the undisturbed functioning of this system in its environment is a certain state of this environment. [...]. The surrounding of a given system is the set of all non-system objects whose properties affect the system and, at the same time, they change under the influence of this system. [...] Failure to meet the needs implies disruption of the system's functioning" (Zbróg, 2011). This definition, in turn, is a contribution to the attempt to create a model of the social logistics system.

One of the types of human needs, of particular importance for this article and understanding the essence of social logistics, are social needs. In order for selected needs to be considered social, they must meet a number of conditions (Lisowski, 1996):

- They should occur universally, and their satisfaction should require the existence of appropriate institutions.

- If not satisfied, they may increase to the extent that justifies the use of institutional or systemic solutions, - When certain social institutions (systems) are characterized by various types of dysfunctions, it is considered necessary to eliminate those dysfunctions.

The above three conditions differ in circumstances in which they occur. With regard to the first condition, social needs are better or worse met by already existing institutions; to the second, meeting the needs requires the establishment of appropriate institutions; while to the third, the needs are relatively difficult to determine. According to Lisowski's 
approach, it can be stated that social needs are all common needs, to which the existence and activity of appropriate institutions are required. Interestingly, however, it does not specify the nature of the needs considered to be social, as the only differentiator assuming their widespread occurrence.

\section{Social Logistics-A Proposal for the System's Composi- tion}

The concept of social logistics system, proposed in this article, assumes a high level of its abstractness. On the basis of systems theory, it can be stated that "an abstract system is defined by means of a set of system elements and a set of relations between elements of this system. Virtually every object can be considered a system, regardless of whether the relations between its elements are the result of the intention of the designer or not. The selection of elements and the way relationships are defined determine the functions that the system performs" (Montasser \& El-Nakeeb, 2017; Myszewski, 1998). This fragment of the article aims to create a model of an abstract social logistics system, containing a proposal of a set of elements in the form of key tasks that it should fulfill. In addition to that, the proposed model contains references to the environment of the social logistics system and suggested flows that should occur within and between it and its surroundings. Figure 1 provides an overview of the concept of social logistics system, including elements of its environment.

Green arrows (Figure 1) indicate the flow of information on social needs. Depending on the type of social need reported, information is collected by implementers of economic (business), military or social logistics. It should be noted that there are situations in which individual entities exchange information about existing social needs, hence the information links between economic, military and social logistics. Red arrows indicate flow (material and information) designed to meet social needs. Symbols: "E1", "E2", "E3" and "E4" are a symbolic representation of a set of elements of the social logistics system, which will be specified later in the article. The concept described in this article is based on the definition adopted by the author of J. Szołtysek and P. Kołodziejczyk, according to which social logistics is "shaping the flows of material (and accompanying information) with a special social role, in order to obtain specific space-time values, resulting from the social needs and ensuring its proper functioning" (Kołodziejczyk \& Szołty- sek, 2009). The authors of the above definition also suggest positioning social logistics next to the other two pure types of logistics, which has an impact on the concept of an abstract system of social logistics. This suggestion and the quoted definition imply the adoption of basic elements of the social logistics system environment. The author of the article considers these elements: a society with particular emphasis on its (social) needs, the general construct of economic logistics and the general construct of military logistics. Each system should be oriented on a specific goal and, in the case of the social logistics system, it is to meet social needs. Hence, the set of social needs is the most important element of the environment of the proposed system.

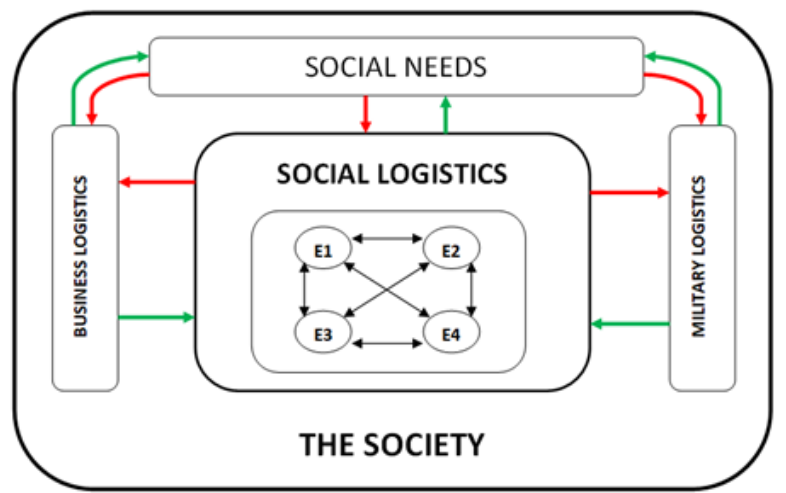

FIGURE 1. A general outline of the concept of the social logistics system and its environment

Table 2 indicates groups of social needs selected by the author in a subjective manner resulting from the analysis of different reports (Black Falds, 2016; New England Healthcare Institution, 2016). For each of the social needs groups, information about the existence of support for the implementation of these needs by social, economic and military institutions has been assigned. In addition to that, an attempt was made to name individual subsystems of the social logistics system.

Table 2 is designed to compose a non-exhaustive, sample set of subsystems of the social logistics system, which may be expanded (or limited) based on further research. This article is conceptual, aimed at stimulating the discussion of academic circles, also in the scope of subsystems of the proposed social logistics system. Another purpose of Table 2 is to justify the occurrence of individual flows indicated in Figure 1. The occurrence of various types of institutions in the process of implementing individual groups of social needs justifies the existence of flows between social, economic and military logistics constructs. 
TABLE 2. Proposed set of subsystems for the social logistics system

\begin{tabular}{|c|c|c|c|c|}
\hline Social Needs Group & $\begin{array}{l}\text { The Support of Social } \\
\text { Institutions }\end{array}$ & $\begin{array}{l}\text { The Support of Busi- } \\
\text { ness Entities }\end{array}$ & $\begin{array}{l}\text { The Support of Mil- } \\
\text { itary Organizations }\end{array}$ & $\begin{array}{l}\text { Proposed Social Logis- } \\
\text { tics Subsystem }\end{array}$ \\
\hline Access to education & + & + & - & Education subsystem \\
\hline Access to housing & + & + & - & Housing subsystem \\
\hline Freedom of employment & + & + & + & Employment subsystem \\
\hline Food safety & + & + & + & Food access subsystem \\
\hline $\begin{array}{l}\text { Current administrative support } \\
\text { (city services) }\end{array}$ & + & - & - & $\begin{array}{l}\text { Administration subsys- } \\
\text { tem }\end{array}$ \\
\hline $\begin{array}{l}\text { Access to socio-demographic in- } \\
\text { formation }\end{array}$ & + & - & - & \\
\hline Limiting interpersonal violence & + & + & + & $\begin{array}{l}\text { Social security subsys- } \\
\text { tem }\end{array}$ \\
\hline Access to financial tools & + & + & - & Finance subsystem \\
\hline Mobility & + & + & + & $\begin{array}{l}\text { Public transport subsys- } \\
\text { tem }\end{array}$ \\
\hline Access to social assistance & + & - & - & \\
\hline Access to childcare & + & + & - & \\
\hline $\begin{array}{l}\text { Prevention and overcoming social } \\
\text { exclusion }\end{array}$ & + & + & - & Social welfare subsystem \\
\hline Addiction prevention & + & + & + & \\
\hline Access to healthcare & + & + & - & Health care subsystem \\
\hline
\end{tabular}

Source : (Black Falds, 2016; Center for Consumer Engagement in Health Innovation, 2018; New England Healthcare Institution, 2016)

\section{THE RESILIENCE IN THE CONTEXT OF SOCIAL LOGIS- TICS}

With the emergence of the need to look for solutions that reduce the increasing vulnerability of logistics systems, there has been a need to find answers to this phenomenon (Liu \& Lee, 2018). Such an answer was considered to be the emergence of the term "resilience", which was supposed to constitute an opposition to the vulnerability to damage and sensitivity to interference (Elleuch, Dafaoui, Elmhamedi, \& Chabchoub, 2016). The starting point for determining what exactly is resilience, in relation to the social logistics system, is, therefore, a set of definitions of the resilience of specific logistics systems, which are the supply chains (Parast et al., 2019). An overview of these definitions is provided in Table 3 .

TABLE 3. Definitions of logistics system's resilience

\begin{tabular}{ll}
\hline \hline Author & Definition \\
\hline Pettit, Fiksel, and Croxton (2010) & The ability of complex industrial systems to survive, adapt, and grow in the face of turbulent change. \\
Gaonkar and Viswanadham (2007) & $\begin{array}{l}\text { Ability to maintain, resume, and restore operations after a disruption. } \\
\text { Datta-Gupta and King (2007) }\end{array}$ \\
& $\begin{array}{l}\text { Not only the ability to resume operations after a disaster, but also a proactive, structured search for } \\
\text { the ability of the supply chain to deal with unforeseen negative phenomena. } \\
\text { The ability of the supply chain to reduce the likelihood of interference and to reduce the effects of such } \\
\text { Fahimnia et al. (2011) }\end{array}$ \\
& $\begin{array}{l}\text { interference, as well as to reduce the time it takes to regain normal performance. } \\
\text { The adaptability of the supply chain to prepare for unexpected events, respond to disruptions, and } \\
\text { maintain business continuity. }\end{array}$ \\
Barroso, Machado, and Machado (2011) & Ability to respond to adverse effects caused by disruptions to maintain supply chain goals. \\
\hline \hline
\end{tabular}

Source: (Barroso et al., 2011; Datta-Gupta \& King, 2007; Fahimnia et al., 2011; Gaonkar \& Viswanadham, 2007; Pettit et al., 2010; Ponomarov \& Holcomb, 2009)

\section{Proposition of a Definition of Social Logistics System's Resilience}

Definitions presented in Table 3, after appropriate modification, may form the basis for determining the definition of social logistics system resilience. This modification is based on the awareness of social logistics' basic goal, which is the fulfillment of social needs and the recognition of the existence of social institutions established to meet those needs.
It can, therefore, be assumed, that the definition of the resilience of social logistics system may be the statement that "The resilience of social logistics system is the ability of social institutions to continually meet social needs in the face of turbulent changes in the environment and to reduce the likelihood of social disturbances, along with minimizing negative effects of their impact". The above construct assumes the need to compose a set of potential social fac- 
tors that disrupt its functioning, as well as a set of factors affecting its vulnerability.

\section{METHODOLOGY OF TESTING THE RESILIENCE OF SO- CIAL LOGISTICS SYSTEM}

The proposed procedure for testing the resilience of social logistics systems will be based on a simplification of the procedure, carried out as part of the doctoral dissertation of the author of this article. The research procedure suggested in this article consists of three stages and a brief description of its course is presented in Table 4 .

The second and third stages of the proposed procedure will be implemented through a modified SCRAM tool for assessing the sensitivity and resilience of supply chains. This tool, based on supply chains, has been based on two dimensions, that are subject to modification for social logistic systems case.

TABLE 4. Stages of the proposed procedure for testing the resilience of social logistics system

\begin{tabular}{|c|c|c|}
\hline Stage & Issue Studied & Research Methods \\
\hline $\begin{array}{l}\text { STAGE I Development of a set of disruptions in } \\
\text { the social logistics system }\end{array}$ & $\begin{array}{l}\text { Identification and classification of disturbances affecting } \\
\text { the resilience of the social logistics system }\end{array}$ & - Analysis of the literature on the subject -Surveys \\
\hline \multirow[t]{2}{*}{$\begin{array}{l}\text { STAGE II Assessment of the degree of vulnerabil- } \\
\text { ity of the social logistics system }\end{array}$} & $\begin{array}{l}\text { Identification of the sensitivity category of the social logis- } \\
\text { tics system }\end{array}$ & - Analysis of the literature on the subject \\
\hline & $\begin{array}{l}\text { Assessment of the degree of sensitivity of the social logis- } \\
\text { tics system }\end{array}$ & - Surveys \\
\hline \multirow[t]{2}{*}{$\begin{array}{l}\text { STAGE III Assessment of the process of manag- } \\
\text { ing the social logistics system's resilience }\end{array}$} & $\begin{array}{l}\text { Determining the ability of the social logistics system to } \\
\text { strengthen resilience }\end{array}$ & - Analysis of the literature on the subject \\
\hline & $\begin{array}{l}\text { Evaluation of the supply chain resilience management } \\
\text { process }\end{array}$ & - Surveys \\
\hline
\end{tabular}

\section{Supply Chain Vulnerability Points (Modification: Social Logistics System Vulnerability Points)}

"basic factors that make the supply chain susceptible to disruption" (Pettit et al., 2010); based on expert research, the authors of the method specified seven sensitivity points, which are described in Table 5. For the purpose of the research procedure proposed in this article, the understanding of these vulnerability points was modified, taking into account social elements affecting the social logistics system.

TABLE 5. Vulnerability points of the supply chain and social logistics system

\begin{tabular}{|c|c|c|c|}
\hline $\begin{array}{l}\text { Vulnerability } \text { Point } \text { (Supply } \\
\text { Chain) }\end{array}$ & Definition (Supply Chain) & $\begin{array}{l}\text { Vulnerability Point (Social Lo- } \\
\text { gistics System) }\end{array}$ & $\begin{array}{l}\text { Definition (Social Lgistics Sys- } \\
\text { tem) }\end{array}$ \\
\hline $\begin{array}{l}\text { V1 Environment changeability } \\
\text { (turbulence) }\end{array}$ & $\begin{array}{l}\text { Environment exposed to frequent } \\
\text { changes of external factors be- } \\
\text { yond the control of the company }\end{array}$ & Changeability of social needs & $\begin{array}{l}\text { The degree of exposure of the so- } \\
\text { cial logistics system to frequent } \\
\text { changes in social needs }\end{array}$ \\
\hline V2 Intentional threats & $\begin{array}{l}\text { Intentional attacks designed to } \\
\text { disrupt the operation or cause } \\
\text { harm to humans or material and } \\
\text { financial damage }\end{array}$ & $\begin{array}{l}\text { Deliberate reduction of quality of } \\
\text { life }\end{array}$ & $\begin{array}{l}\text { Intentional attacks aimed at dis- } \\
\text { rupting the quality of life of soci- } \\
\text { ety }\end{array}$ \\
\hline V3 External pressure & $\begin{array}{l}\text { Existence of external tensions } \\
\text { causing business barriers }\end{array}$ & $\begin{array}{l}\text { Pressure of other types of logis- } \\
\text { tics }\end{array}$ & $\begin{array}{l}\text { Existence of tensions from eco- } \\
\text { nomic and military logistics im- } \\
\text { plementers }\end{array}$ \\
\hline V4 Resource restrictions & $\begin{array}{l}\text { Restrictions due to the lack of } \\
\text { availability of resources for pro- } \\
\text { duction and distribution }\end{array}$ & Resource restrictions & $\begin{array}{l}\text { Limitations resulting from the } \\
\text { lack of availability of resources } \\
\text { necessary to meet social needs }\end{array}$ \\
\hline V5 Process sensitivity & $\begin{array}{l}\text { The importance of strictly con- } \\
\text { trolling the conditions for the im- } \\
\text { plementation of processes and } \\
\text { materials used }\end{array}$ & Process sensitivity & $\begin{array}{l}\text { The importance of strictly con- } \\
\text { trolling the conditions for meet- } \\
\text { ing social needs }\end{array}$ \\
\hline V6 Dependence on partners & $\begin{array}{l}\text { Degree of dependence on external } \\
\text { partners }\end{array}$ & Dependence on partners & $\begin{array}{l}\text { Degree of dependence on repre- } \\
\text { sentatives of economic and mili- } \\
\text { tary logistics }\end{array}$ \\
\hline $\begin{array}{l}\text { V7 Interference from suppli- } \\
\text { ers/customers }\end{array}$ & $\begin{array}{l}\text { Susceptibility of suppliers and } \\
\text { customers to external forces or } \\
\text { interference }\end{array}$ & $\begin{array}{l}\text { Interference from representa- } \\
\text { tives of other types of logistics }\end{array}$ & $\begin{array}{l}\text { Interference transmitted from } \\
\text { representatives of economic and } \\
\text { military logistics }\end{array}$ \\
\hline
\end{tabular}

Source: (Pettit et al., 2010) 
Supply Chain Capabilities (Modification: Social Logistics System Capabilities)

defined as "attributes that enable the supply chain to anticipate and resist disruptions" (Pettit et al., 2010). Based on expert research, the authors of the method specified the supply chain capabilities, which are described in Table 6 . For the purposes of the research procedure proposed in this article, the understanding of these capabilities was modified, taking into account social elements affecting the social logistics system.

TABLE 6. Capabilities strengthening the supply chain resilience and capabilities of the social logistics system

\begin{tabular}{|c|c|c|c|}
\hline Capability (Supply Chain) & Definition (Supply Chain) & $\begin{array}{l}\text { Capability (Social Logistics Sys- } \\
\text { tem) }\end{array}$ & $\begin{array}{l}\text { Definition (Social Logistics Sys- } \\
\text { tem) }\end{array}$ \\
\hline C1 Supply flexibility & $\begin{array}{l}\text { Ability to quickly change supply } \\
\text { sources }\end{array}$ & Institutional flexibility & $\begin{array}{l}\text { Ability to use the resources of } \\
\text { commercial and military institu- } \\
\text { tions }\end{array}$ \\
\hline C2 Flexibility in order processing & $\begin{array}{l}\text { Ability to quickly change means of } \\
\text { transport or other factors related } \\
\text { to the implementation of orders }\end{array}$ & Flexibility to meet needs & $\begin{array}{l}\text { Ability to quickly change physi- } \\
\text { cal factors related to meeting the } \\
\text { needs }\end{array}$ \\
\hline $\begin{array}{l}\text { C3 Availability of means of pro- } \\
\text { duction }\end{array}$ & $\begin{array}{l}\text { Availability of means to ensure a } \\
\text { constant level of production }\end{array}$ & $\begin{array}{l}\text { Availability of means of produc- } \\
\text { tion }\end{array}$ & $\begin{array}{l}\text { Availability of funds to ensure a } \\
\text { continuous flow of goods in the } \\
\text { context of meeting needs }\end{array}$ \\
\hline C4 Visibility (awareness) & $\begin{array}{l}\text { Knowledge of operating assets } \\
\text { and the environment }\end{array}$ & Visibility (awareness) & $\begin{array}{l}\text { Knowledge of operating assets } \\
\text { and the environment }\end{array}$ \\
\hline C5 Predictability & $\begin{array}{l}\text { The ability to see potential future } \\
\text { events or situations }\end{array}$ & Predictability & $\begin{array}{l}\text { The ability to see potential future } \\
\text { social needs }\end{array}$ \\
\hline C6 Renewability & $\begin{array}{l}\text { The ability to quickly recover } \\
\text { from a disturbance }\end{array}$ & Renewability & $\begin{array}{l}\text { The ability to quickly recover } \\
\text { from a disturbance }\end{array}$ \\
\hline C7 Dispersion & $\begin{array}{l}\text { Wide distribution or decentral- } \\
\text { ization of assets }\end{array}$ & Dispersion & $\begin{array}{l}\text { Wide distribution or decentral- } \\
\text { ization of assets }\end{array}$ \\
\hline C8 Cooperation & $\begin{array}{l}\text { Ability to work effectively with ex- } \\
\text { ternal parties for mutual benefits }\end{array}$ & Cooperation & $\begin{array}{l}\text { Ability to work effectively with } \\
\text { representatives of economic and } \\
\text { military logistics for mutual ben- } \\
\text { efits }\end{array}$ \\
\hline C9 Organization & $\begin{array}{l}\text { Organizational structures, poli- } \\
\text { cies, skills, organizational culture }\end{array}$ & Organization & $\begin{array}{l}\text { Organizational structures, poli- } \\
\text { cies, skills, organizational culture }\end{array}$ \\
\hline
\end{tabular}

Source: (Pettit et al., 2010)

The individual elements of the above two tables will be assessed on a five-point Likert scale (from 1 to 5) using a survey in which respondents will answer a series of questions as part of each of the supply chain's vulnerability or capability points. The survey will, first of all, be addressed to representatives of high schools and universities located in the Upper Silesian-Zagłębie Metropolis and their answers will be reflected in the assessment of individual elements of the vulnerability or capability of the social logistics system. In the simplest variant of the proposed tool, the general point assessment of the sensitivity of the social logistics system will be the arithmetic average of the ratings of individual sensitivity points, while the general point assessment of the ability of social logistics system to predict and counteract interference in a form of an arithmetic average of assessments of individual capabilities. This approach is a significant simplification, and thus it is suggested to use an additional study to determine the importance of individual vulnerability points and the capability of the system under consideration. The assessments obtained in this way can be subjected to extensive analysis. The individual elements of the above two tables will be assessed on a fivepoint Likert scale (from 1 to 5) using a survey in which respondents will answer a series of questions as part of each of the supply chain's vulnerability or capability points. The survey will, first of all, be addressed to representatives of high schools and universities located in the Upper SilesianZagłębie Metropolis and their answers will be reflected in the assessment of individual elements of the vulnerability or capability of the social logistics system. In the simplest variant of the proposed tool, the general point assessment of the sensitivity of the social logistics system will be the arithmetic average of the ratings of individual sensitivity points, while the general point assessment of the ability of social logistics system to predict and counteract interference in a form of an arithmetic average of assessments of individual capabilities. This approach is a significant simplification, and thus it is suggested to use an additional study to determine the importance of individual vulnerability points and the capability of the system under consideration. The 
assessments obtained in this way can be subjected to extensive analysis.

This article presents the results of pilot studies on the assessment of individual capabilities of social logistics system to shape resilience from the point of view of representatives of secondary schools and higher education institutions from the area of Upper Silesia (and a control group from the area of the Polish capital -Warsaw). Pilot studies described in this article did not include the vulnerability points described in Table 5. Pilot studies, the results of which are described in this chapter, were conducted in September 2019 on a sample of 138 representatives of high schools and universities from Poland. The research sample included 104 representatives of the Upper Silesian-Zagłębie Metropolis and, for contrast, 34 representatives of the capital city of Warsaw. The surveys were carried out on a purposely selected group of students from a selected high school and university located in Upper Silesia and a purposely selected group of students from Warsaw. The research sample structure is presented in Figure 2. Described pilot studies are part of the research procedure described in Table 4 and apply to the assessment of the process of managing the social logistics system's resilience (Stage III of research procedure - Table 4). The research was based on the modified SCRAM tool. Respondents were asked to determine the compliance of 43 statements (divided into 9 sections - see Table 7) with their beliefs. Respondents stated compliance with the statements on a five-point Likert scale, where 1 means complete disagreement and 5 means complete agreement with the statement. Additionally, respondents assessed the importance of a particular resilience strengthening ability. The final assessment of the social logistic system resilience can be calculated according to formula :

$$
R E S=\frac{\sum_{i=1}^{9} C_{i} * I M P_{c_{i}}}{\sum_{i=1}^{9} I M P_{c_{i}}}
$$

Where:

- $C_{i}$ - Scoring for the strengthening ability

$-I M P_{C i}$ - Assessment of the significance of the strengthening ability

The maximum achievable indicator of the social logistic system resilience (maximum assessment of each of the indicated capabilities) is 5 .

\section{Survey Structure}

The structure of the survey assumes the occurrence of a number of statements relating to each of the 9 capabilities of the social logistics system. The number of statements relating to each of the abilities is presented in Table 7.

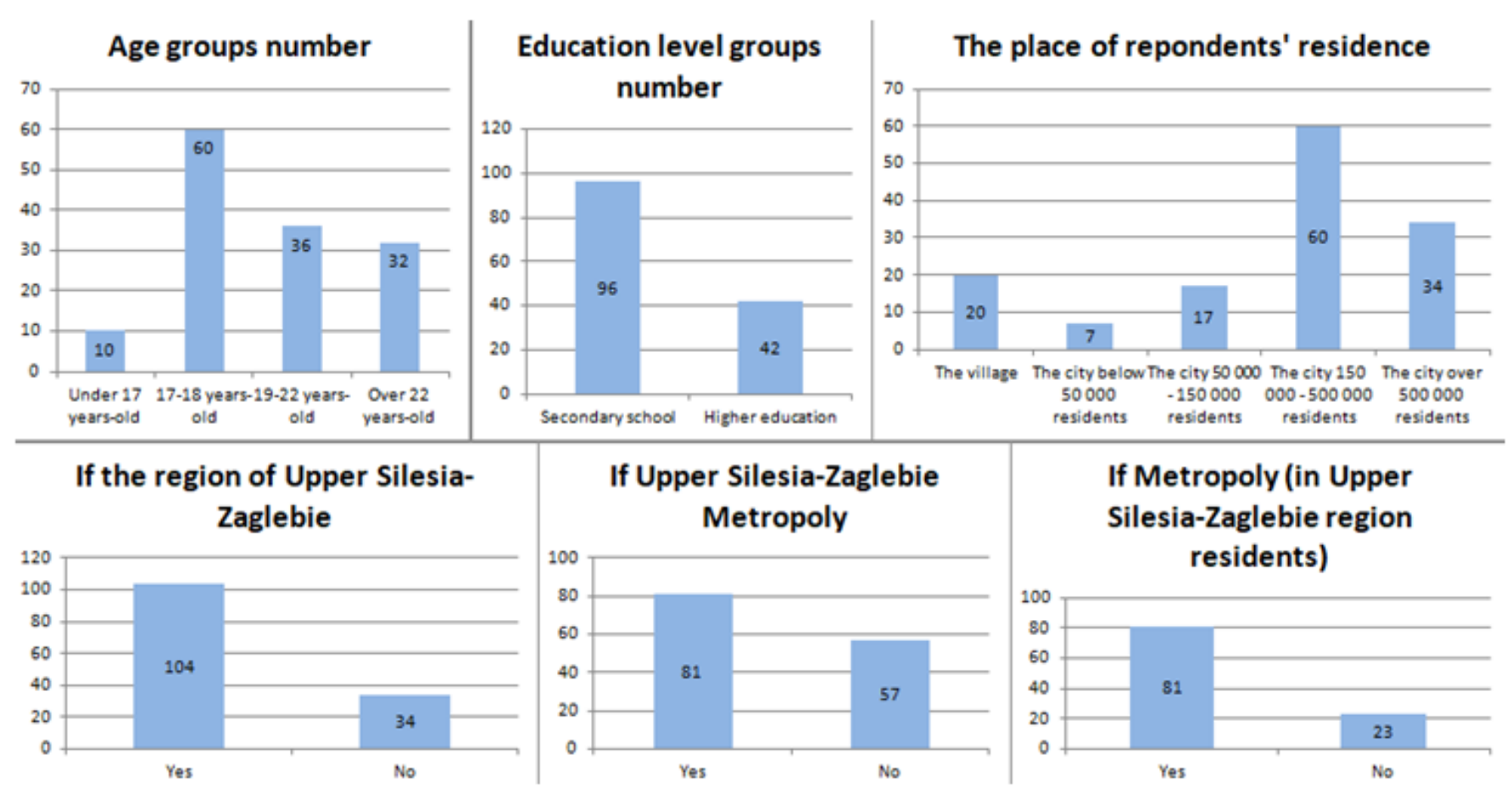

FIGURE 2. The research sample structure 
TABLE 7. Number of statements related to each capability

\begin{tabular}{lll}
\hline \hline Capability (Social Logistics System) & Definition (Social Logistics System) & $\begin{array}{l}\text { Number of Statements in The } \\
\text { Survey }\end{array}$ \\
\hline C1 Institutional flexibility & $\begin{array}{l}\text { Ability to use the resources of commercial and mil- } \\
\text { itary institutions }\end{array}$ & 5 \\
C2 Flexibility to meet needs & $\begin{array}{l}\text { Ability to quickly change physical factors related to } \\
\text { meeting the needs }\end{array}$ & 5 \\
& Availability of funds to ensure a continuous flow of & 4 \\
C3 Availability of means of production & goods in the context of meeting needs & \\
& Knowledge of operating assets and the environ- & 7 \\
C4 Visibility (awareness) & ment & 3 \\
& The ability to see potential future social needs & 3 \\
C5 Predictability & The ability to quickly recover from a disturbance & 3 \\
C6 Renewability & Wide distribution or decentralization of assets & 4 \\
C7 Dispersion & Ability to work effectively with representatives of & 5 \\
C8 Cooperation & economic and military logistics for mutual benefits & \\
& Organizational structures, policies, skills, organi- & 7 \\
C9 Organization & zational culture & \\
& & \\
\hline \hline
\end{tabular}

\section{THE RESILIENCE OF SOCIAL LOGISTICS SYSTEM PILOT STUDY'S RESULTS}

Tables 8 and 9 present the results of calculating the average values of respondents' answers to the questions within the individual capabilities of the system to shape resilience.

\section{Capabilities Rating Without Significance}

Table 8 presents the values calculated for individual regions taken into account in the analysis, while Table 9 - the values for individual ranges of the population of the respondents' places of residence.

In the case of most of the capabilities $(\mathrm{C} 1, \mathrm{C} 2, \mathrm{C} 3, \mathrm{C} 4, \mathrm{C} 7$, $\mathrm{C} 8, \mathrm{C} 9$ ), the highest rates were observed in the group of respondents living in the capital city of Warsaw. For capabilities $\mathrm{C} 5$ and $\mathrm{C} 6$ (predictability and renewability), the highest rates were observed in the group living in the Upper SilesiaZaglebie region.

TABLE 8. Scoring for each capability without significance according to region

\begin{tabular}{|c|c|c|c|c|c|c|c|c|c|}
\hline & C1 & $\mathrm{C} 2$ & C3 & C4 & C5 & C6 & C7 & C8 & C9 \\
\hline Upper Silesia-Zaglebie region & 3.362 & 3.619 & 4.077 & 3.731 & 2.279 & 3.179 & 3.909 & 3.390 & 3.565 \\
\hline Upper Silesia-Zaglebie Metropolis & 3.548 & 3.886 & 4.102 & 3.792 & 2.243 & 3.263 & 4.093 & 3.521 & 3.670 \\
\hline Warsaw Metropolis & 4.412 & 3.941 & 4.529 & 3.899 & 1.941 & 2.706 & 4.397 & 4.059 & 3.756 \\
\hline Entire research sample & 3.620 & 3.699 & 4.188 & 3.772 & 2.196 & 3.063 & 4.029 & 3.555 & 3.612 \\
\hline
\end{tabular}

TABLE 9. Scoring for each capability without significance, according to respondents' place of residence

\begin{tabular}{llllllllll}
\hline \hline & C1 & C2 & C3 & C4 & C5 & C6 & C7 & C8 & C9 \\
\hline Village & 2.760 & 2.570 & 3.925 & 3.350 & 2.167 & 2.867 & 3.075 & 2.860 & 3.043 \\
City below 50 000 residents & 2.771 & 3.486 & 4.107 & 3.796 & 2.714 & 3.381 & 3.214 & 3.714 & 3.531 \\
City 50 000 - 150 000 residents & 3.612 & 3.871 & 4.015 & 3.824 & 1.686 & 2.843 & 4.206 & 3.494 & 3.580 \\
City 150 000 - 500 000 residents & 3.560 & 3.913 & 4.142 & 3.824 & 2.433 & 3.356 & 4.183 & 3.500 & 3.738 \\
City over 500 000 residents & 4.412 & 3.941 & 4.529 & 3.899 & 1.941 & 2.706 & 4.397 & 4.059 & 3.756 \\
Entire research sample & 3.620 & 3.699 & 4.188 & 3.772 & 2.196 & 3.063 & 4.029 & 3.555 & 3.612 \\
\hline \hline
\end{tabular}

Analysis of the data contained in Table 9 indicates that the larger the urban unit of evaluation relates to, the higher indicators observed for individual capabilities. Exceptions to this rule, similarly to Table 8, are capabilities 5 and 6 (predictability and renewability).

\section{Capabilities Importance Evaluation}

Table 10 presents the average levels of significance of individual capabilities of the social logistics system to shape its resilience perceived by respondents and the standard deviation of these significances in the research sample.

TABLE 10. Capabilities average importance

\begin{tabular}{llllllllll}
\hline \hline & IMP & IMP & IMP & IMP & IMP & IMP & $\begin{array}{l}\text { IMP } \\
\text { C7 }\end{array}$ & $\begin{array}{l}\text { IMP } \\
\text { C8 }\end{array}$ & $\begin{array}{l}\text { IMP } \\
\text { C9 }\end{array}$ \\
\hline Capabilities average significance & 4.848 & 7.746 & 7.072 & 6.522 & 5.717 & 7.949 & 6.399 & 5.261 & 7.804 \\
Standard deviation & 1.317 & 0.838 & 1.407 & 1.618 & 1.944 & 0.969 & 1.212 & 1.539 & 1.066 \\
\hline \hline
\end{tabular}


Due to the lack of significant differences in the perception of the significance of individual capabilities of the social logistics system to build resilience within individual groups of the research sample, Table 10 presents only the average significance of each ability observed for the entire research sample. From the point of view of respondents (the users of social logistics systems), the most important for shaping resilience are capabilities C2, C3, C6, and C9. The group of capabilities of minor significance includes capabilities C1,
C5 and C8.

\section{Resilience Shaping Capabilities Evaluation (With Signif- icance)}

Calculated average values of the resilience indicator of the social logistics system depending on the considered region and the average for individual capacities to shape resilience, taking into account their significance, are presented in Table 11 and Figures 3 and 4 .

TABLE 11. Capabilities ratings with importance and average resilience indicator by region

\begin{tabular}{|c|c|c|c|c|c|c|c|c|c|c|}
\hline & $\begin{array}{c}\text { C1 } \\
\text { Rating }\end{array}$ & $\begin{array}{l}\text { C2 } \\
\text { Rating }\end{array}$ & $\begin{array}{l}\text { C3 } \\
\text { Rating }\end{array}$ & $\begin{array}{l}\text { C4 } \\
\text { Rating }\end{array}$ & $\begin{array}{l}\text { C5 } \\
\text { Rating }\end{array}$ & $\begin{array}{l}\text { C6 } \\
\text { Rating }\end{array}$ & $\begin{array}{l}\text { C7 } \\
\text { Rating }\end{array}$ & $\begin{array}{l}\text { C8 } \\
\text { Rating }\end{array}$ & $\begin{array}{l}\text { C9 } \\
\text { Rating }\end{array}$ & $\begin{array}{l}\text { Average Resilience } \\
\text { Indicator }\end{array}$ \\
\hline Upper Silesia- & 0.277 & 0.477 & 0.508 & 0.402 & 0.227 & 0.428 & 0.416 & 0.295 & 0.472 & 3.501 \\
\hline \multicolumn{11}{|l|}{ Zaglebie region } \\
\hline $\begin{array}{l}\text { Upper Silesia- } \\
\text { Zaglebie }\end{array}$ & 0.292 & 0.512 & 0.515 & 0.399 & 0.226 & 0.437 & 0.444 & 0.310 & 0.482 & 3.618 \\
\hline \multicolumn{11}{|l|}{ Metropolis } \\
\hline Warsaw & 0.364 & 0.506 & 0.473 & 0.439 & 0.200 & 0.358 & 0.494 & 0.379 & 0.487 & 3.702 \\
\hline \multicolumn{11}{|l|}{ Metropolis } \\
\hline $\begin{array}{l}\text { Entire research } \\
\text { sample }\end{array}$ & 0.299 & 0.484 & 0.499 & 0.411 & 0.220 & 0.411 & 0.436 & 0.316 & 0.476 & 3.500 \\
\hline
\end{tabular}

In the case of capabilities $\mathrm{C} 1, \mathrm{C} 4, \mathrm{C} 7, \mathrm{C} 8, \mathrm{C}$, the highest rating (with significance) was achieved by Warsaw Metropolis. For almost all (excepting C4 - visibility) of these capabilities, the rating of Upper Silesia-Zaglebie Metropolis was higher than the rating of the Upper Silesia-Zaglebie region (the region includes some small places with low population, especially villages). For capabilities $\mathrm{C} 2, \mathrm{C} 3, \mathrm{C} 5$ and $\mathrm{C} 6$, the rating achieved by Upper Silesia-Zaglebie Metropolis was higher than those from Warsaw Metropolis. The average resilience indicator is the highest for Warsaw Metropoly, the second-highest rating was observed for Upper SilesiaZaglebie Metropoly. This observation suggests the connection between the population of respondents' place of residence and the average resilience indicator. Table 12 presents results for different groups on the basis of this criterion to test above-mentioned supposition.

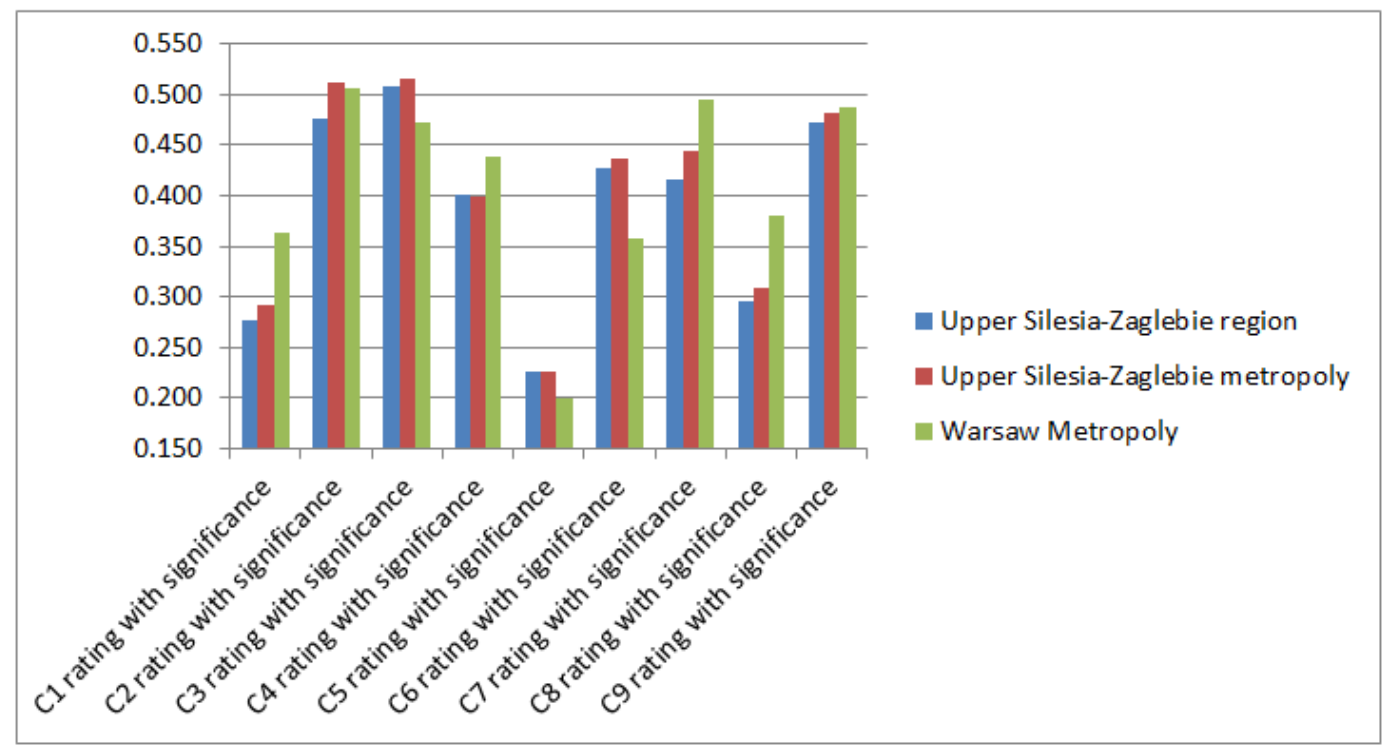

FIGURE 3. Capabilities ratings with significance by region 


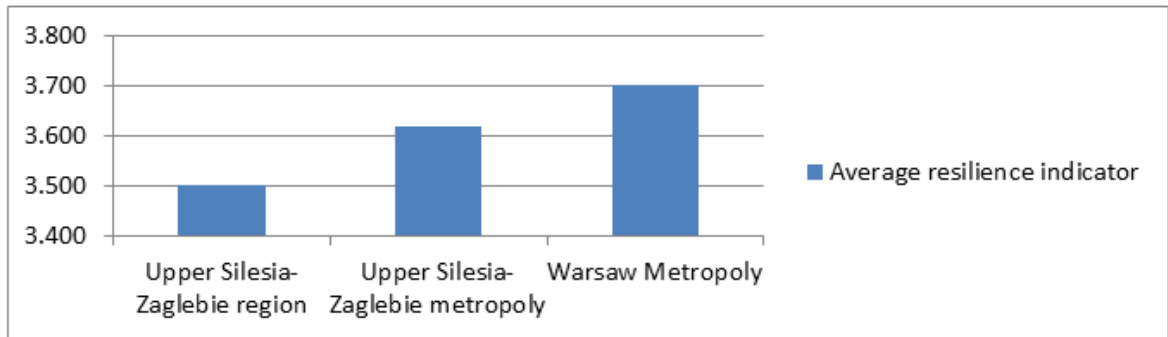

FIGURE 4. The average resilience indicator by region

Calculated average values of the resilience of the social logistics system and the average for individual capacities to shape resilience, taking into account their significance, were also analyzed on the basis of respondents' place of residence. Values for this criterion are presented in Table 12 and Figures 5 and 6.

TABLE 12. Capabilities ratings with importance and average resilience indicator by place of residence

\begin{tabular}{|c|c|c|c|c|c|c|c|c|c|c|}
\hline & $\begin{array}{c}\text { C1 } \\
\text { Rating }\end{array}$ & $\begin{array}{l}\text { C2 } \\
\text { Rating }\end{array}$ & $\begin{array}{l}\text { C3 } \\
\text { Rating }\end{array}$ & $\begin{array}{l}\text { C4 } \\
\text { Rating }\end{array}$ & $\begin{array}{l}\text { C5 } \\
\text { Rating }\end{array}$ & $\begin{array}{l}\text { C6 } \\
\text { Rating }\end{array}$ & $\begin{array}{l}\text { C7 } \\
\text { Rating }\end{array}$ & $\begin{array}{l}\text { C8 } \\
\text { Rating }\end{array}$ & $\begin{array}{l}\text { C9 } \\
\text { Rating }\end{array}$ & $\begin{array}{l}\text { Average Resilience } \\
\text { Indicator }\end{array}$ \\
\hline Village & 0.230 & 0.336 & 0.467 & 0.400 & 0.225 & 0.388 & 0.311 & 0.237 & 0.403 & 2.996 \\
\hline $\begin{array}{l}\text { City below } 50 \\
000 \text { residents }\end{array}$ & 0.254 & 0.471 & 0.536 & 0.457 & 0.260 & 0.442 & 0.368 & 0.287 & 0.429 & 3.503 \\
\hline $\begin{array}{l}\text { City } 50000-150 \\
000 \text { residents }\end{array}$ & 0.355 & 0.484 & 0.481 & 0.437 & 0.103 & 0.408 & 0.432 & 0.362 & 0.480 & 3.541 \\
\hline $\begin{array}{l}\text { City } 150000 \text { - } \\
500 \quad 000 \text { resi- } \\
\text { dents }\end{array}$ & 0.274 & 0.523 & 0.526 & 0.386 & 0.258 & 0.445 & 0.453 & 0.296 & 0.498 & 3.658 \\
\hline $\begin{array}{l}\text { City over } 500 \\
000 \text { residents }\end{array}$ & 0.364 & 0.506 & 0.473 & 0.439 & 0.200 & 0.358 & 0.494 & 0.379 & 0.487 & 3.702 \\
\hline
\end{tabular}

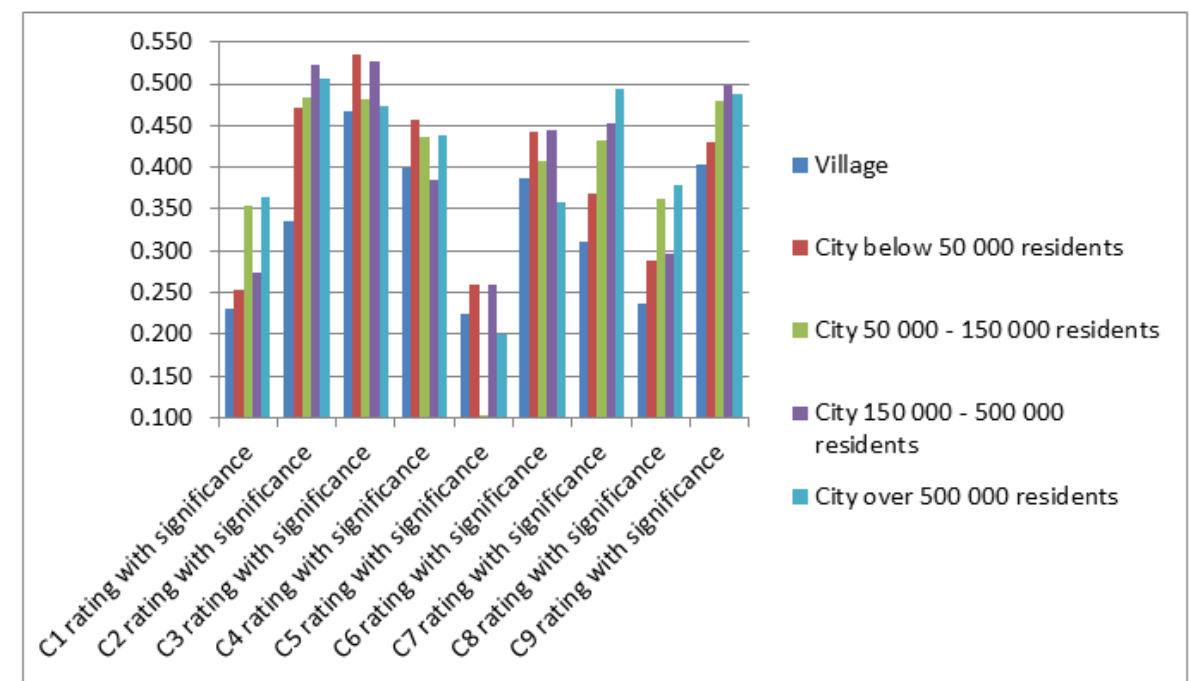

FIGURE 5. Capabilities ratings with importance by respondents' place of residence

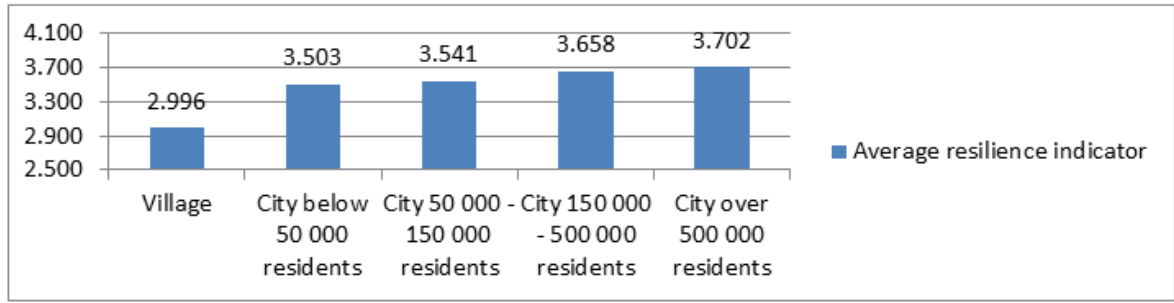

FIGURE 6. The average resilience indicator by respondents' place of residence 
Based on the analysis of Table 12 and Figures 5 and 6 , the supposition of increasing resilience, together with the increase in the population of the respondents' place of residence in question, seems to be confirmed only in the case of the average resilience indicator. In the case of component indicators (capability indicators), such a relationship cannot be seen. In order to deepen the analysis of the above assumption, an analysis of Pearson's correlation between the size of the population of the respondents' place of residence and weighted indices of individual abilities and the average index was carried out.

\section{Correlation between the Size of The Respondents' Place of Residence and Resilience Shaping Capabilities}

Table 12 suggests that there may be a relationship between the place of residence of the respondents and the assessments of individual capabilities of the social logistics system to shape resilience, taking into account their significance. To test the accuracy of the above hypothesis, Pearson correlation coefficients were calculated.

Table 13 presents the matrix of Pearson 's correlation between the population of the respondents' place of residence and the social logistics system resilience indicator and individual capabilities for building resilience.

TABLE 13. Correlation matrix between respondents' place of residence and resilience indicators

\begin{tabular}{|c|c|c|c|c|c|c|c|c|c|c|}
\hline & $\begin{array}{l}\text { Average } \\
\text { Resilience } \\
\text { Indicator }\end{array}$ & $\begin{array}{l}\text { C1 } \\
\text { Rating }\end{array}$ & $\begin{array}{l}\text { C2 } \\
\text { Rating }\end{array}$ & $\begin{array}{l}\text { C3 } \\
\text { Rating }\end{array}$ & $\begin{array}{l}\text { C4 } \\
\text { Rating }\end{array}$ & $\begin{array}{l}\text { C5 } \\
\text { Rating }\end{array}$ & $\begin{array}{l}\text { C6 } \\
\text { Rating }\end{array}$ & $\begin{array}{l}\text { C7 } \\
\text { Rating }\end{array}$ & $\begin{array}{l}\text { C8 } \\
\text { Rating }\end{array}$ & $\begin{array}{l}\text { C9 } \\
\text { Rating }\end{array}$ \\
\hline \multirow{2}{*}{$\begin{array}{l}\text { Respondents } \\
\text { of residence }\end{array}$} & 0.514 & 0.324 & 0.462 & 0.035 & 0.029 & 0.021 & -0.039 & 0.525 & 0.332 & 0.287 \\
\hline & $p=0.000$ & $p=0.000$ & $p=0.000$ & $p=0.683$ & $p=0.734$ & $p=0.811$ & $p=0.652$ & $p=0.000$ & $p=0.000$ & $p=0.001$ \\
\hline
\end{tabular}

The analysis presented in Table 13 shows that statistically significant ( $p$-value $<0.05$ ) correlations were observed as follows:

-Moderate (0.514) positive correlation between the population of respondents' place of residence and average resilience indicator.

- Weak (0.324) positive correlation between the population of respondents' place of residence and institutional flexibility rating (with significance).

- Moderate (0.462) positive correlation between the population of respondents' place of residence and flexibility to meet needs rating (with significance).

- Moderate (0.525) positive correlation between the population of respondents' place of residence and dispersion rating (with significance).

- Weak (0.332) positive correlation between the population of respondents' place of residence and cooperation rating (with significance).

- Weak (0.287) positive correlation between the population of respondents' place of residence and organization rating (with significance).

No statistically significant correlations were observed between the population of respondents' place of residence and other capabilities.

Even a relatively small research sample, which is the subject of the described pilot study, allows finding certain statistically significant relationships between the size of the population of the respondent's place of residence and the ability indicators affecting the resilience of the social logistics system. This observation suggests that it is worth conducting an in-depth research on a broader research sample and in a larger territorial area, covering various urban areas.

\section{CONCLUSION}

This article, which is one of the links in a series of publications on the research on the resilience of social logistics systems, presents basic assumptions, justifying the use of the system approach for the subject of social logistics and the results of pilot studies aimed at determining the level of selected systems' resilience. The second chapter of the article summarizes the basic assumptions about the isolation of social logistics as one of the three pure types of logistics and refers to the general theory of systems. The third chapter is an attempt to transfer the concept of the resilience of supply chains into the reality of social logistics systems. From the respondents' point of view, the most important capabilities for achieving the primary goal of social logistics - meeting the needs of system users include the ability to quickly change physical factors related to meeting the needs, the availability of funds to ensure a continuous flow of goods in the context of meeting needs, the ability to quickly recover from a disturbance, as well as organizational structures, policies, skills and organizational culture.

\section{LIMITATIONS AND RECOMMENDATIONS}

A relatively small research sample makes it impossible to unequivocally interpret the results of the study, although 
the conclusions from the analysis of indicator data give rise to a number of interesting assumptions that should be verified during extensive research. In addition to that, the presented pilot studies are only a fragment of the full research procedure, whose overall application is a future research challenge for the author of this article. This observation suggests that urban managers should focus their attention on resource allocation, aimed at ensuring the highest possible level of the abovementioned capabilities. It can be worrisome that, among the most important abilities for residents, only the availability of funds to ensure a continuous flow of goods in the context of meeting needs has a highvalue index, while the rest of the most important abilities require increased efforts to strengthen them. By far, the lowest indicators, without taking into account the significance, were observed in the case of the ability to see potential future social needs, which suggests the need to implement certain tools, aimed at regular measurement of residents' satisfaction and listening to their needs, in order to improve the functioning of logistic flows affecting the fulfillment of the basic needs of society, which is the primary goal of social logistics.

\section{REFERENCES}

Barroso, A., Machado, V., \& Machado, V. C. (2011). Supply chain resilience using the mapping approach. In Supply chain management. New York, NY: InTech.

Bhalerao, S. (2016). Role of emotional intelligence in organizational conflict management. International Journal of Business and Administrative Studies, 2(2), 37-43.

Black Falds. (2016). Town of blackfalds social needs assessment master plan. Retrieved from https://bit. ly/36MceTc

Blaik, P., \& Logistyka, L. (2001). Koncepcja zintegrowanego zarzqdzania. Warsaw, Poland: Polskie Wydawnictwo Ekonomiczne.

Center for Consumer Engagement in Health Innovation. (2018). Screening for social needs. Retrieved from https://bit. ly/ 2S4UnS7

Coyle, J. J., Bardi, E. J., \& Langley, C. J. (2007). Zarzä dzanie logistyczne. Warsaw, Poland: Polskie Wydawnictwo Ekonomiczne.

Datta-Gupta, A., \& King, M. J. (2007). Streamline simulation: Theory and practice. New York, NY: Society of Petroleum Engineers Richardson.

Elleuch, H., Dafaoui, E., Elmhamedi, A., \& Chabchoub, H. (2016). Resilience and vulnerability in supply chain: Literature review. IFAC Papers on Line, 49(12), 1448-1453. doi:https://doi.org/10.1016/j.ifacol.2016.07.775

Fahimnia, B., Molaei, R., \& Ebrahimi, M. H. (2011). Integration in logistics planning and optimization. California, CA: Elsevier Insights.

Gallopin, G. C., Hammond, A., Raskin, P., \& Swart, R. (1997). Branch points: Global scenarios and human choice. New York, NY: Citeseer.

Gaonkar, R. S., \& Viswanadham, N. (2007). Analytical framework for the management of risk in supply chains. Transactions on Automation Science and Engineering, 4(2), 265-273. doi:https://doi.org/10.1109/tase.2006.880540

Han, H., \& Trimi, S. (2018). A fuzzy TOPSIS method for performance evaluation of reverse logistics in social commerce platforms. Expert Systems with Applications, 103, 133--145. doi:https://doi.org/10.1016/j.eswa.2018.03.003

Klumpp, M., \& Zijm, H. (2019). Logistics innovation and social sustainability: How to prevent an artificial divide in human-computer interaction. Journal of Business Logistics, 40(3), 265--278. doi:https://doi.org/10.1111/jbl.12198

Kołodziejczyk, P., \& Szołtysek, J. (2009). Epistemologia logistyki społecznej. Przegląd Organizacji, 3(4), 21-24. doi:https:// doi.org/10.33141/po.2009.04.06

Krzyżanowski. (1994). Essences of organization and management sciences. Warsaw, Poland: Polskie Wydawnictwo Ekonomiczne.

Lisowski, A. (1996). Badanie potrzeb spoĺ ecznych. Warszawa, Poland: Biblioteka Pracownika Socjalnego.

Liu, C.-L., \& Lee, M.-Y. (2018). Integration, supply chain resilience, and service performance in third-party logistics providers. The International Journal of Logistics Management, 29(1), 5-21. doi:https://doi.org/10.1108/ijlm-11-2016-0283

McGihon, R., Hawke, L. D., Chaim, G., \& Henderson, J. (2018). Cross-sectoral integration in youth-focused health and social services in canada: A social network analysis. BMC Health Services Research, 18(1), 901-920. doi:https://doi.org/ 10.1186/s12913-018-3742-1

Michlowicz, E. (2002). Podstawy logistyki przemysí owej. Krakow, Poland: AGH Uczelniane Wydawnictwa NaukowoDydaktyczne. 
Montasser, M. H. H., \& El-Nakeeb, I. (2017). Investigating solid waste supply chain: A proposed framework for achieving the environmental sustainability case study Alexandria, Egypt. International Journal of Business and Economic Affairs, 2(3), 165-172. doi:https://doi.org/10.24088/ijbea-2017-23001

Myszewski, J. M. (1998). Zarzq̨dzanie zmiennościq̨: Systemowe spojrzenie na metody statystyczne w zarządzaniu jakością. Warsaw, Poland: Instytut Organizacji i Zarządzania w Przemyśle.

New England Healthcare Institution. (2016). Social needs screening toolkit. Retrieved from https://bit . 1y/38TjsX6

Niedzielska, E. (1998). Informatyka ekonomiczna, wyd. Wroclaw, Poland: AE we Wrocławiu.

Parast, M., Sabahi, S., \& Kamalahmadi, M. (2019). The relationship between firm resilience to supply chain disruptions and firm innovation. In Zsidisin G., and Henke M. (Eds), Revisiting supply chain risk. New York, NY: Springer.

Pettit, T. J., Fiksel, J., \& Croxton, K. L. (2010). Ensuring supply chain resilience: Development of a conceptual framework. Journal of Business Logistics, 31(1), 1-21. doi:https://doi.org/10.1002/j.2158-1592.2010.tb00125.x

Piyachat, B. (2017). The relationships among resources' commitment reverse logistics innovation reverse logistics performance and reverse logistics cost savings: Manufacturing vs service industry. Journal of Administrative and Business Studies, 3(3), 122-135. doi:https://doi.org/10.20474/jabs-3.3.2

Ponomarov, S. Y., \& Holcomb, M. C. (2009). Understanding the concept of supply chain resilience. The International Journal of Logistics Management, 20(1), 124-143. doi:https://doi.org/10.1108/09574090910954873

Rudolf, S. (2002). Employee entrepreneurship: Stages of problem solving (Unpublished master thesis). Department of Economics, University of Lodz, Lodz, Poland.

Szołtysek, J., Sadowski, A., \& Kalisiak-Mędelska, M. (2016). Logistyka społeczna (Unpublished master's thesis). Universty of Lodz, Lodz, Poland.

Trujillo, 0. G. V. (2009). Logistica global: Una nueva estrategia corporativa, gestio polis 04. Retrieved from https: //bit . ly/ 37 JwTZD

Von Bertalanffy, L. (1984). Ogólna teoria systemów: Podstawy, rozwój, zastosowania. Warsaw, Poland: Państwowe Wydawnictwo Naukowe.

Zbróg, Z. (2011). Identyfikowanie i zaspokajanie potrzeb społecznych w niepublicznych szkołach podstawowych. Lodz, Poland: Oficyna Wydawnicza Impuls. 